\title{
Phenotypic Performance of Kambro Crossbreeds of Female Broiler Cobb 500 and Male Pelung Blirik Hitam
}

\author{
(PERFORMA FENOTIPIK KAMBRO HASIL PERSILANGAN ANTARA BETINA BROILER \\ COBB 500 DAN JANTAN PELUNG BLIRIK HITAM)
}

\section{Wayan Swarautama Mahardhika ${ }^{1 *}$, Budi Setiadi Daryono ${ }^{1}$}

${ }^{1}$ Gama Ayam Research Team, Laboratory of Genetics and Breeding, Faculty of Biology, Universitas Gadjah Mada, Jl. Teknika Selatan, Sinduadi, Mlati, Kabupaten Sleman, Daerah Istimewa Yogyakarta, Indonesia 55281.

*Email: i.wayan.sm@mail.ugm.ac.id

\begin{abstract}
This research was conducted to measure the phenotypic performance of Kambro crossbreeds of Pelung Blirik Hitam and Broiler Cobb 500. Based on Body Weight (BT) measurement, the Kambro population $(\mathrm{n}=17)$ has an average $B T$ of $1,244.14 \pm 453.82$ grams significant $(\mathrm{p}<0.01)$ to $\mathrm{F}_{1}$ Pelung $(\mathrm{n}$ $=7$ ) with an average BT of $602.88 \pm 79.93$ grams in 8 -weeks period with ad libitum diet of standard feed. Phenotypic performance of Kambro significant to $\mathrm{F}_{1}$ Pelung based on the measurement of linear bodyweight parameter, vitality parameter, $\mathrm{PPa}-\mathrm{PBe}$ parameter, and phenotype parameter. Kambro has the phenotype combination of parental generation based on phenotype parameters. PPa parameter was suitable BT estimation model based on non-linear quadratic regression $(\mathrm{r}=0.956)$ with formula 1.84E3 $\pm 3.54 \mathrm{E} 2 * \mathrm{x}+31.73 * \mathrm{x}^{2}$. The difference between the chicken group $(\mathrm{p}<0.014)$ was significant to BT and the interaction between the group and linear bodyweight parameter was not significant based on ANCOVA. The mortality rate of Kambro was lower than $\mathrm{F}_{1}$ Pelung with the absence of vaccination in a semi-intensive rearing system. As the size of the hybrid's population was limited, research findings must be validated with a larger population size of the hybrid.
\end{abstract}

Keywords: Broiler Cobb 500; grandparent stock; Kambro; Pelung Blirik Hitam; selective breeding.

\begin{abstract}
ABSTRAK
Riset ini diadakan dengan tujuan mengukur performa fenotipik Kambro hasil persilangan antara Pelung Blirik Hitam dan Broiler Cobb 500. Berdasarkan pengukuran Bobot Tubuh (BT), rerata BT Kambro $(n=17)$ mencapai 1.244,14 $\pm 453,82$-gram signifikan $(\mathrm{p}<0,01)$ terhadap $\mathrm{F}_{1}$ Pelung $(\mathrm{n}=7)$ dengan rerata BT 602,88 \pm 79,93-gram pada umur 8 minggu dengan diet pakan standar ad libitum. Performa fenotipik Kambro signifikan terhadap $\mathrm{F}_{1}$ Pelung berdasarkan parameter bobot tubuh linear, parameter vitalitas, parameter $\mathrm{PPa}-\mathrm{PBe}$ dan parameter fenotipe. Kambro memiliki perpaduan fenotipe indukannya berdasarkan parameter fenotipe. Parameter PPa merupakan model estimasi BT Kambro berdasarkan regresi non-linear quadratic $(\mathrm{r}=0,956)$ dengan formula $1,84 \mathrm{E} 3 \pm 3,54 \mathrm{E} 2 * \mathrm{x}+31,73 * \mathrm{x}^{2}$. Perbedaan grup antar grup signifikan $(\mathrm{p}<0,014)$ terhadap BT dan tidak terdapat interaksi antara grup dan parameter bobot tubuh linear berdasarkan ANCOVA. Tingkat mortalitas Kambro lebih rendah dibandingkan $F_{1}$ Pelung tanpa vaksinasi dengan sistem pemeliharaan semi-intensif. Sebagai akibat dari ukuran populasi hibrida terbatas, temuan riset harus divalidasi dengan ukuran populasi hibrida lebih besar.
\end{abstract}

Kata kunci: Broiler Cobb 500; grandparent stock; Kambro; Pelung Blirik Hitam; persilangan selektif.

\section{INTRODUCTION}

Pusat Data dan Sistem Informasi Pertanian (2015) stated that the chicken meat consumption rate of 2014 reached $4.48 \mathrm{~kg} / \mathrm{capita} /$ year (total consumption of broiler chicken, post-laying layer chicken, and male layer also native chicken). The chicken poultry sector contributed around $60.73 \%$ of the demand on animal consumption needs fulfillment (Suprijatna, 2010). Ditjen PKH (2017) showed that native chicken production nationally 
reached $8.50 \%$ or 284.9 thousand tons with a contribution percentage of $12.86 \%$ to national chicken meat production. Ditjen PKH (2018) showed that Indonesia's poultry livestock populations in 2018 consisted of 1.8 billion-broiler-type/broiler chickens, 181.752-layer chickens, and 310.960-native chickens. Broiler-type and laying-type chicken poultry industry went through significant growth per year driven by improvement in income and knowledge on healthy nutritional-balance food products (Iskandar, 2017). The chicken poultry industry in Indonesia is still dependent on imported broiler caused by a short production period and rapid turnover (Nurfadillah et al., 2018).

Native chicken has unlimited potential to become broiler-type, egg-type, and dualpurpose chicken candidates to fulfill domestic consumption needs of animalbased food through selective and genetic engineering (Nataamijaya, 2010; Henuk and Bakti, 2018; Kartika et al., 2016). Native Indonesia chickens are called Kampung chickens or native (non-breed chickens) to differentiate commercial breeds such as Cobb, Hubbar, Hybro, Isa Hyline, and Hisex (Henuk and Bakti, 2018). Identification of native chicken germplasm resulted in 34 breeds of chicken consist of Ayunai, Balenggek, Banten, Bangkok, Burgo, Bekisar, Cangehgar, Cemani, Ciparage, Gaok, Jepun, Kampung, Kasintu, Kedu (Hitam and Putih), Pelung, Lamba, Maleo, Melayu, Merawang, Nagrak, Nunukan, Nusa Penida, Olagan, Rintit or Walik, Sedayu, Sentul, Siem, Sumatera, Tolaki, Tukung, Wareng, Sabu, and Semau (Henuk and Bakti, 2018). Approximately 11 native chicken breeds are categorized as candidates of broilertype and laying-type chicken (Henuk and Bakti, 2018). Native Indonesia chickens have to be maintained optimally to support small-scale poultry industry based on native chickens. Native Indonesia chicken's germplasm can be the solution for fulfilling the increasing domestic food consumption demand (Daryono et al., 2010). Ningsih and
Prabowo (2017) stated that various challenges faced by poultry industry subsector especially broiler, besides market integration several factors including production, productivity, and competitiveness of poultry product. Nurfadillah et al. (2018) stated that the agribusiness problem in the subsystem of broiler chicken poultry is economic efficiency in poultry level added by highcost production inflicted by dependence on imported raw-material of feed. Improvement of efficiency and poultry product quality are decided by the supply of superior chicken breed, feed demand fulfillment, and good rearing management system (Anggitasari et al., 2016). Improvement of productivity and competitive quality of local broiler chicken can be achieved through selective breeding of native Indonesia chicken breeds. Selective breeding is aimed to produce superior chicken breed with adjusted phenotype quality based on human needs (Das et al., 2008; Cheng, 2010; Oldenbroek and van der waaij, 2014; Mariandayani et al., 2017; Sudrajat and Isyanto, 2018).

Pelung Blirik Hitam has several distinguished characters such as posture and body weight compared with other native breeds (Daryono et al., 2010). The bodyweight of males Pelung chicken can reach $3.37 \mathrm{~kg}$ and females can reach $2.52 \mathrm{~kg}$ (Daryono et al., 2010). Broiler Cobb 500 has distinguished productivity and a high growth rate in the grower phase (7 to 18 weeks). Male and female Broiler Cobb 500 can reach 1,599.17 grams and 1,540.46 grams (Hassan et al., 2016). This research is aimed to measure the phenotypic performance of hybrid chicken Kambro based on research conducted by Tamzil et al. (2018) to Cairina moschata and Daryono et al. (2010) to hybrids from crossbreeds of Pelung with Cemani with the addition and adaptation of measurement parameters. Measurement parameters used in this research are estimation model of body weight, body weight growth, linear bodyweight parameter, mortality rate, 
phenotypes, and vitality parameter. Empowerment of native Indonesia chicken can contribute to the availability of food sources and support native Indonesia chicken germplasm conservation (Suprijatna, 2010; Sudrajat and Isyanto, 2018).

\section{RESEARCH METHODS}

This research was conducted in Pusat Inovasi Agroteknologi (PIAT), Kali Tirto, Berbah, Sleman Regency, Yogyakarta using 4 females Broiler Cobb 500 and 1 male Pelung Blirik Hitam, 1 female Pelung Blirik Hitam, $7 \mathrm{~F}_{1}$ Pelung chickens, 22 Broiler Cobb 500 chickens and 17 Kambro $\left(\mathrm{F}_{1}\right.$ Broiler) chickens. $\mathrm{F}_{1}$ Pelung was produced from crossbreeds of Pelung Blirik Hitam native to Cianjur, West Java (Fig. 1B). Broiler Cobb 500 was produced by the rearing of Day-Old-Chicken (DOC) Broiler Cobb 500 from Pokphand Indonesia. Kambro ( $\mathrm{F}_{1}$ Broiler) was produced from crossbreeds of 4 female Broiler Cobb 500 aged 6 months with a male Pelung Blirik Hitam (Fig. 1A). Parental crossbreeding was conducted in a brood shed $\left(8 \mathrm{~m}^{2}\right)$ owned by Gama Ayam Research Team. Standard feeds produced by PT. Japfa Comfeed Indonesia, AD II (brood/juvenile, 9-22 weeks) and BR-1 (starter, 0-22 days) with ad libitum dietary. Supplemental vitamin Egg Stimulant ${ }^{\circledR}$ and TetraChlor ${ }^{\circledR}$ produce by Medion were needed to improve immunity and brood productivity. Egg collection from each crossbreed was hatched using an incubator. Day-OldChicken (DOC) was reared intensively in bamboo pens insulated by plywood and equipped with incandescent lamps (15 watts). Chicken at 4-weeks-old then transferred into a larger shed with a semiintensive rearing system $\left(8 \mathrm{~m}^{2}\right)$. Grouping of each chicken based on its crossbreeding as follows DOC $\mathrm{F}_{1}$ Pelung (group I), DOC Broiler Cobb 500 (group II), and DOC Kambro (group III). Bodyweight growth of DOC Broiler, DOC $\mathrm{F}_{1}$ Pelung, and DOC Kambro was measured per week with digital scale KrisChef EK9350H with 0.01- gram accuracy until chicken reaches 8weeks-old. Zoometric measurement was measured with metline based on morphological guidance of chicken skeletal (Supplemental Files, adapted with modification and addition from Daryono et al., 2010).

1. TA was measured from the digit/hallux to the tip of the comb

2. TB was measured from the digit/hallux to the end of the distal vertebrae

3. LP was measured from articular to dexter

4. PP was measured from the base of the angular process to the end of the mandibular symphysis

5. PK was measured from the supraorbital bone to the premaxilla

6. LK was measured from quadratojugal sinister to dexter

7. TJ was measured from the highest tip of the comb to the base of the comb

8. PJ was measured from the back to the front of the comb

9. PB was measured from the tip of the first thoracic vertebra to the base of the pygostyle

10. LB was measured from the base of the femoral bone to dexter

11. LD was measured from the sternal of the keel in a circle

12. $\mathrm{PPu}$ was measured from the thoracic vertebrae to the caudal vertebrae end

13. PS was measured from the base of the humerus to the end of the carpus

14. PL was measured from the base of the atlas to the tip of the thoracic vertebrae

15. PBe was measured from the tip of the femur to the base of the tibiotarsus

16. PPa was measured from the end of the patella to the base of the femur

Linear bodyweight parameter consists of TA (chicken height), TB (body height), PB (body length), LB (body width), PPu (dorsal length), PL (neck length), PS (wingspan) and LD (chest circumference). The vitality parameter consists of TJ (comb height), PJ (comb length), PK (head length), LK (head width), PP (beak length), and LP (beak width). Qualitative phenotype 
parameter including neck feather color, dorsal/ back feather color, chest feather color, body feather color, femoral feather color, shank color, comb color, comb shape, and beak color. Phenotype parameter of hybrid is identified as visual data with the black background photo. The weekly data record consists of bodyweight growth (BT) and femur-tibia length (PPa-PBe). Data is analyzed with correlation, regression, one-way ANOVA, and independent sample t-test using IBM $^{\odot}$ SPSS $^{\odot}$ Statistics version 21. An independent sample t-test can be used to compare average bodyweight, body growth, feed intake, feed conversion, and mortality rate between two chicken populations (Darwati et al., 2016). Correlation between femur-tibia length and linear bodyweight parameter to bodyweight growth are analyzed with Pearson correlation method, linear regression, multiple linear regression, and analysis of covariance (ANCOVA). Phenotype parameter is analyzed with visual observation scoring method based on photo.

\section{RESULTS AND DISCUSSION}

Crossbreeds of female Broiler Cobb 500 with male Pelung Blirik Hitam produced 18 hybrids named Kambro consisted of 9 males Kambro and 9 females Kambro (Fig. 1A 1-2). Crossbreeds of female Pelung Blirik Hitam with male Pelung Blirik Hitam produced $22 \mathrm{~F}_{1}$ Pelung

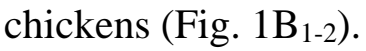

Day-Old-Chicken (DOC) of control populations consist of $\mathrm{F}_{1}$ Pelung and Broiler Cobb 500 each with 22 chickens. The mortality rate of group III (Kambro), group II (Broiler Cobb 500), and group I ( $\mathrm{F}_{1}$ Pelung) subsequently are $5.5 \%, 0 \%$, and $68.2 \%$. The mortality rate of group $\mathrm{I}$ is higher than group III and II. The earliest record of death was in the group I at 2weeks-old meanwhile in group III at 6weeks-old. The most probable cause of death in group I and group III were caused by infection of infectious coryza (snot) through daily observation. Infectious coryza (snot) disease is caused by gramnegative bacteria Haemophilus paragallinarum with the symptom of rapid infection and high morbidity, declining in egg production, oculonasal conjunctivitis, face swelling, and conjunctival sac exudation (Ali et al., 2013; Iskandar, 2017).

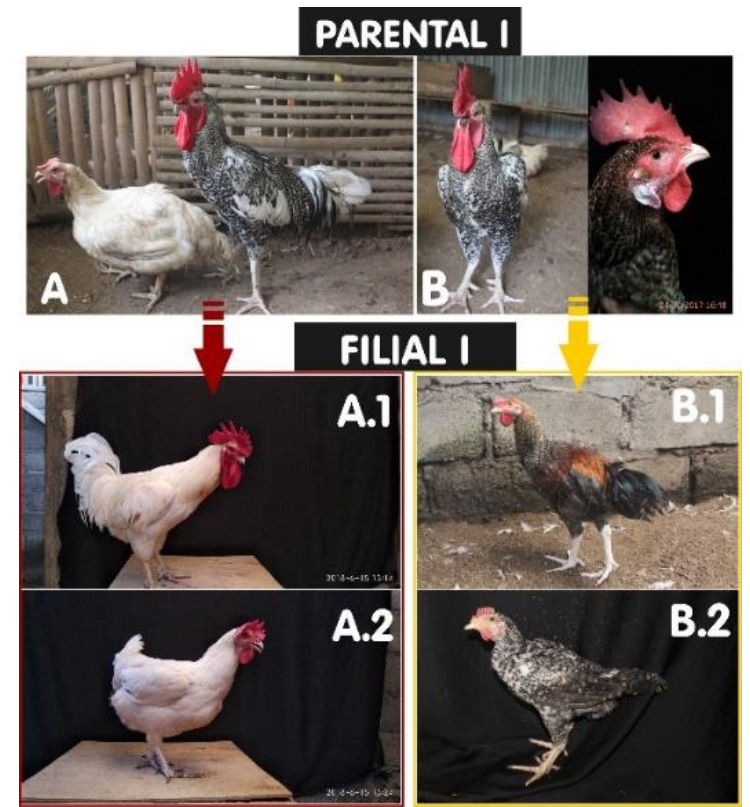

Figure 1. Chicken cross diagram. Parental I (A: female Broiler Cobb 500 and male Pelung Blirik Hitam; B: female Pelung Blirik Hitam and male Pelung Blirik Hitam) and Filial I (A.1: male Kambro; A.2: female Kambro; B.1: male $\mathrm{F}_{1}$ Pelung; B.2: female $\mathrm{F}_{1}$ Pelung) (Personal Documentation, 2017)

The absence of vaccination was a treatment to assess the immunity of each chicken group. Data of mortality from each group lead to a conclusion that the immunity resistance of group III was higher than group I. High mortality rate can be caused by the absence of vaccination in group I and III. Group II had been vaccinated since hatching by DOC producer. Kampung chicken has distinguished immunity resistance better than other native tropical broiler-type breeds and highest expression of antivirus gene $M x+$ (Diwyanto and Prijono, 2007; Nuroso, 2010; Kartika et al., 2016; Nurhuda, 2017). Kambro has higher immunity resistance indicates an 
improvement of the genetic quality of native chicken through crossbreed and semi-intensive rearing system supported by management and environmental factors.

Egg collection and hatching of Kambro was 10 until 20 eggs per week during 6 months period (December 2017 until May 2018). Egg productivity rate was low at 20 until 22 eggs on the peak of Broiler Cobb 500 laying cycle. Female Broiler Cobb 500 ( \pm 6 months) hatchability only reaches $25 \%$ per hatching period. Several factors were influencing the fluctuation of Kambro's egg productivity including nutrition, stress level, sperm fertility, and egg fertility. Laying broiler productivity reaches its peak of laying cycle at the age of 23 weeks ( \pm 6 months) (Rahman et al., 2015). Female Broiler Cobb 500 egg productivity in this research can be influenced by female age. Hameed et al. (2016) stated that egg weight and hatchability can be influenced by female aging, declining hatchability of eggs reach $15 \%$ in female broiler at 30-weeksold with egg weight less than 60 grams. The main factor that influenced the fluctuation of egg productivity can be caused by ad libitum standard feed dietary. Rahman et al. (2015) stated that ad libitum dietary can decrease egg productivity, minimizing egg hatchability, and increasing mortality rate. Feed diet restriction must be implemented to limiting bodyweight growth, maximizing egg production, and increase the female Broiler Cobb 500 fertility (Rahman et al., 2015).

In Table 1 are shown the results of oneway ANOVA analysis of $\mathrm{PPa}, \mathrm{PBe}$, and $\mathrm{BT}$ on each chicken groups which significantly different $(\mathrm{p}<0.01)$. BT shows a highly significant $(p<0.01)$ difference in three groups of chicken $[\mathrm{F}(2,43)=62.09$, $\mathrm{p}<0.01, \eta 2=0.743]$. PPa shows a highly significant $(\mathrm{p}<0.01)$ difference in three groups of chicken $[\mathrm{F}(2,43)=55.09$, $\mathrm{p}<0.01, \eta 2=0.719]$. PBe shows a highly significant $(\mathrm{p}<0.01)$ difference in three groups of chicken $[\mathrm{F}(2,43)=22.87$, $\mathrm{p}<0.01, \eta 2=0.515]$. Post hoc analysis with Fisher's LSD indicates a significant difference of $\mathrm{PPa}, \mathrm{PBe}$ and $\mathrm{BT}$ on each of chicken groups. PPa of group I ( $\mathrm{M}=6.79$, $\mathrm{SD}=1.03)$ significant to group II $(\mathrm{M}=$ $5.69, \mathrm{SD}=0.82)$ and group III $(\mathrm{M}=8.92$, $\mathrm{SD}=1.08)$. PBe of group $\mathrm{I}(\mathrm{M}=8.9, \mathrm{SD}=$ $0.82)$ significant to group II $(\mathrm{M}=11.25, \mathrm{SD}$ $=0.85)$ and group III $(\mathrm{M}=11.96, \mathrm{SD}=1.2)$. $\mathrm{BT}$ of group $\mathrm{I}(\mathrm{M}=602.88, \mathrm{SD}=79.93)$ significant to group II $(\mathrm{M}=1,706.82, \mathrm{SD}=$ 262.54) and group III $(\mathrm{M}=1,244.14, \mathrm{SD}=$ 453.82). Conclusively group III shows a distinguished performance of BT, PPa and PBe compare with group I (Fig. 2A). BT of group III $(1,244.14 \pm 453.82$ gram $)$ approaches BT of group II $(1,706.82 \pm$ 262.54 gram) at 8-weeks-old. One-way ANOVA analysis of $\mathrm{PPa}, \mathrm{PBe}$, and $\mathrm{BT}$ is strengthened with independent sample ttest (Supplemental File 3, Table 2). PPa of group III $(\mathrm{M}=8.92, \mathrm{SD}=1.08)$ is significant to group I $(\mathrm{M}=6.79, \mathrm{SD}=1.03)$, $\mathrm{t}(22)=4.446, \mathrm{p}<.001)$. PPa of group III (M $=8.92, \mathrm{SD}=1.08)$ is significant to group II $(\mathrm{M}=6.79, \mathrm{SD}=1.03), \mathrm{t}(37)=10.62$, $\mathrm{p}<.001)$. PBe of group III $(\mathrm{M}=8.92, \mathrm{SD}=$ $1.08)$ is significant to group $\mathrm{I}(\mathrm{M}=6.79, \mathrm{SD}$ $=1.03), \mathrm{t}(22)=5.956, \mathrm{p}<0.01)$. PBe of group III $(\mathrm{M}=8.92, \mathrm{SD}=1.08)$ is significant to group $\mathrm{I}(\mathrm{M}=6.79, \mathrm{SD}=1.03)$, $\mathrm{t}(37)=2.139, \mathrm{p}<0.05)$. BT of group III $(\mathrm{M}$ $=8.92, \mathrm{SD}=1.08)$ is significant to group I $(\mathrm{M}=6.79, \mathrm{SD}=1.03), \mathrm{t}(21.66)=9.88$, $\mathrm{p}<0.01)$. Variance test with Levene's test of BT group III-I indicates a dissimilarity $(\mathrm{F}=$ $11.11, p=0.003$ ), as adjustment the degree of freedom is set from 22 into 21.66 . 


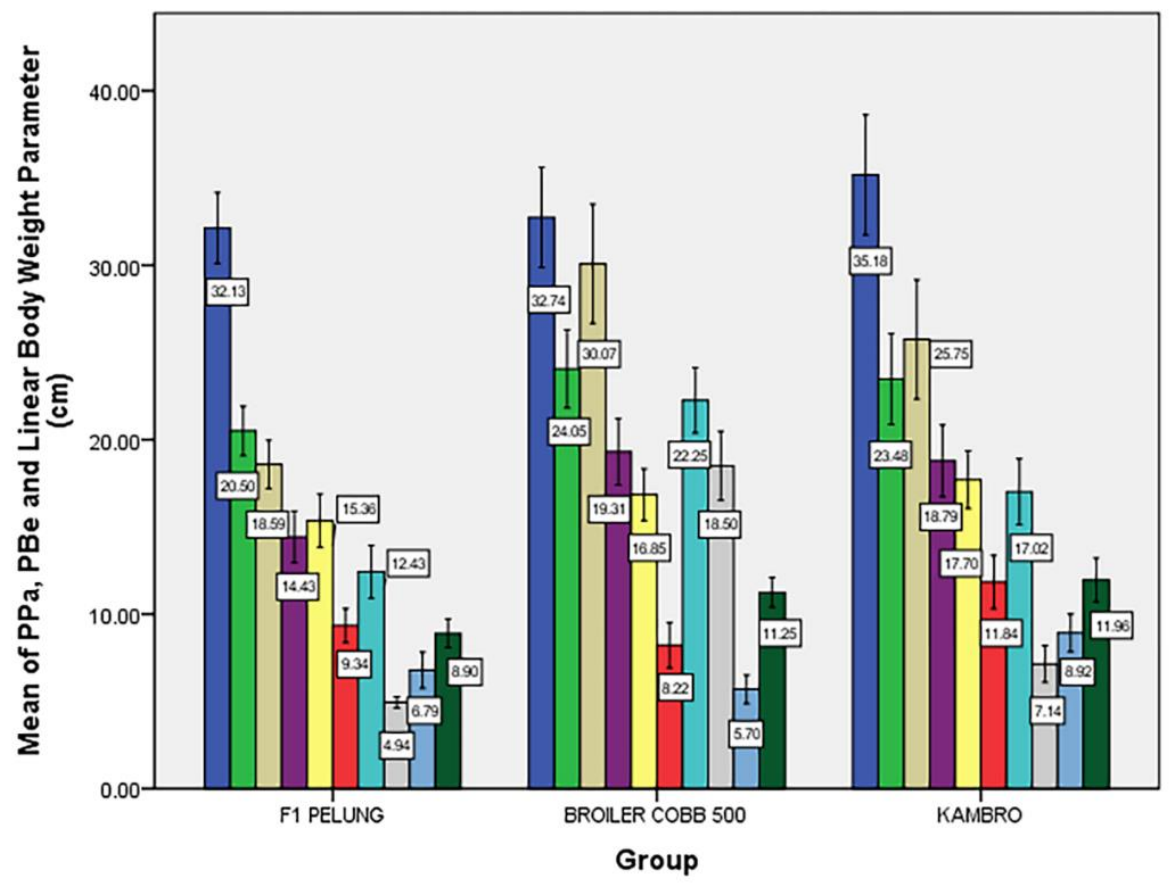

Error Bars: +/- $1 \mathrm{SD}$

(A)

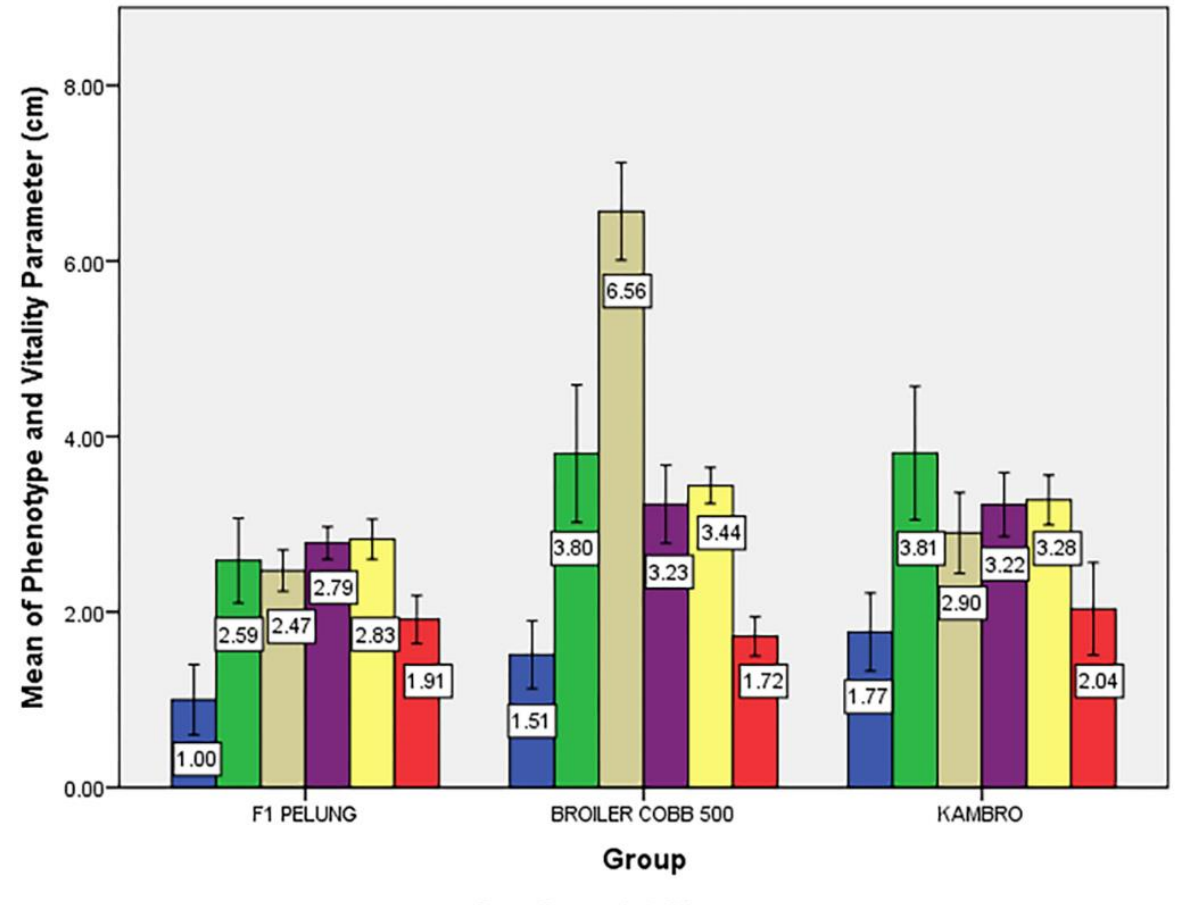

(B)

Figure 2. (A) Mean of PPa, PBe, and linear bodyweight parameters of group I, II, and III in 8weeks; (B) The mean parameters of the chicken group I, II, and III vitality and phenotype in 8weeks. The standard deviation is denoted by T-bar. In graph A, each parameter is symbolized by arrangement: TA $\square$; TB $\square$; PB $\square$; LB $\square$; LD $\square$; PPu $\square$; PS $\square$; PL $\square$; PBe $\square$; PPa $\square$. In graph B, each parameter is symbolized by arrangement: LP $\square$; PP $\square$; PK $\square$; LK $\square$; TJ $\square$; PJ 
Table 1. Analysis of One-Way ANOVA PPa, PBe, and BT Chicken Groups I, II, and III at 8weeks

\begin{tabular}{|c|c|c|c|c|c|}
\hline \multirow{2}{*}{ Parameters } & \multicolumn{3}{|c|}{ Chicken Groups } & \multirow[b]{2}{*}{$\mathrm{F}$} & \multirow{2}{*}{$\eta 2$} \\
\hline & $\mathrm{I}(\mathrm{n}=7)$ & II $(\mathrm{n}=22)$ & III $(n=17)$ & & \\
\hline $\mathrm{PPa}(\mathrm{cm})$ & $6.79 \mathrm{a}(1.03)$ & $5.69 \mathrm{~b}(0.82)$ & $8.92 \mathrm{ab}(1.08)$ & $55.09^{* * * *}$ & 0.719 \\
\hline $\mathrm{PBe}(\mathrm{cm})$ & $8.9 \mathrm{a}(0.82)$ & $11.25 \mathrm{~b}(0.85)$ & $11.96 \mathrm{ab}(1.2)$ & $22.87^{* * * *}$ & 0.515 \\
\hline BT (gram) & 602.88a (79.93) & $1,706.82 \mathrm{~b}(262.54)$ & $1,244.14 \mathrm{ab}(453.82)$ & $62.09^{* * *}$ & 0.743 \\
\hline
\end{tabular}

$\mathrm{PPa}=$ Femur Length

$\mathrm{PBe}=$ Tibia Length

BT $=$ Body Weight

$*=\mathrm{p}<0.05 ; * * *=\mathrm{p}<0.01$. The standard deviation is listed below the mean. The averages with different subscripts in the same column differ significantly $(\mathrm{p}<0.05)$ based on Fisher's LSD post hoc.

The average Body Weight (BT) of Kambro at 8-weeks-old can be compared with other similar crossbreeds. Crossbreeding of Sentul chicken reached an average body weight of $896.34 \pm 55.46$ grams (male Sentul) and $736.00 \pm 46.63$ grams (female Sentul) for 75 days period (Solikin et al., 2016; Sudrajat and Isyanto, 2018). Mariandayani et al. (2013) stated data about bodyweight of native chicken at 8-weeks-old which including Pelung (male 458.23 grams and female 420.11 grams), Sentul (male 406.36 grams and female 355.98 grams), Kampung (male 411.56 grams and female 358.74 grams). From these comparisons can be concluded that Kambro can reach higher BT than other native chicken breeds. Hasyim (2015) stated that hybrids chicken crossbreeds of Kampung and Broiler at 12-weeks-old can reach 2,335 grams (male) and 1,833 grams (female). Kambro bodyweight growth at 8weeks-old has not reached the inflection point whereas Kambro BT's growth projection was estimated to be higher as weeks follow. The inflection point is maximum bodyweight growth, during this period a shift of growth phase occurs with declining growth. Growth can occur during weeks follow because the chicken has not reached sexual maturity (Sogindor, 2017). Suprijatna (2010) stated that the sexual maturity of Pelung chicken at day-165 with 12-weeks-old weight can reach 669 grams. Nurhuda (2017) stated that genetic component combination affects BT of chicken from crossbreeding with hybrids observed to have better performance than a parental generation on several characters or traits. Average BT of Kambro was 1,244.14 \pm 453.82 grams lower than Broiler Cobb 500 which can reach 1,706.82 \pm 262.54 grams at 8-weeks-old for the reason of only inherited $50 \%$ of Broiler Cobb 500 genetic components, whereas BT of $\mathrm{F}_{1}$ Pelung only reached $602.88 \pm 79.93$ grams with the same period.

$\mathrm{PPa}, \mathrm{PBe}$, and several linear bodyweight parameters have correlations with chicken bodyweight (Ukwu et al., 2014). Linear bodyweight parameters consist of shank length, chest circumference, tibia length, neck length, dorsal length, and femur length (Ukwu et al., 2014). Linear bodyweight parameters used in this research consist of TA, TB, LB, PL, PS, LD, and PPu. Linear bodyweight parameter has a significant influence on the selective breeding program, also as chicken bodyweight indicator and market attraction (Ukwu et al., 2014; Assan, 2015). LD and $\mathrm{PB}$ in group III showed significant $(\mathrm{p}<0.01)$ results than group II, meanwhile TA, PL, and LB in group III were superior to group II (Table 2). Performance improvement of Kambro to Pelung was shown by significant results of linear bodyweight parameter in group III and group I. PPa, $\mathrm{PBe}$, and linear bodyweight parameter correlation to BT is summarized in Table 2. 
Table 2. Correlation of linear bodyweight parameter, PPa, and PBe to BT in chicken group I, II, and III

\begin{tabular}{|c|c|c|c|c|}
\hline & \multicolumn{4}{|c|}{ Chicken Groups } \\
\hline \multicolumn{2}{|l|}{ Parameters $(\mathrm{cm})$} & $I(n=7)$ & II $(n=22)$ & III $(n=17)$ \\
\hline \multirow{8}{*}{$\begin{array}{l}\text { Linear Body Weight } \\
\text { Parameters }\end{array}$} & TA & $-0.374^{\mathrm{ns}}$ & $0.444^{*}$ & $0.553^{*}$ \\
\hline & $\mathrm{TB}$ & $-0.091^{\mathrm{ns}}$ & $0.380^{\dagger}$ & $0.633^{* *}$ \\
\hline & LB & $0.344^{\mathrm{ns}}$ & $0.216^{\mathrm{ns}}$ & $0.629^{* *}$ \\
\hline & $\mathrm{PB}$ & $0.150^{\mathrm{ns}}$ & $0.005^{\mathrm{ns}}$ & $0.478^{\dagger}$ \\
\hline & PL & $-0.454^{\mathrm{ns}}$ & $0.361^{\dagger}$ & $0.152^{\mathrm{ns}}$ \\
\hline & PS & $0.792^{*}$ & $0.179^{\mathrm{ns}}$ & $0.606^{* *}$ \\
\hline & LD & $0.131^{\mathrm{ns}}$ & $-0.398^{\dagger}$ & $0.396^{\mathrm{ns}}$ \\
\hline & $\mathrm{PPu}$ & $0.431^{\mathrm{ns}}$ & $0.349^{\mathrm{ns}}$ & $0.299^{\mathrm{ns}}$ \\
\hline \multirow{2}{*}{\multicolumn{2}{|c|}{$\begin{array}{l}\mathrm{PPa} \\
\mathrm{PBe}\end{array}$}} & $0.975^{* * *}$ & $0.932^{* * *}$ & $0.965^{* * *}$ \\
\hline & & $0.298^{\mathrm{ns}}$ & $-0.064^{\mathrm{ns}}$ & $0.567^{*}$ \\
\hline
\end{tabular}

Table 3. Chicken group X linear bodyweight parameter factor (FAC1_1) ANCOVA Body Weight (BT) at 8-weeks

\begin{tabular}{lcccc}
\hline Source & $D f$ & $F$ & $\eta 2$ & $p$ \\
\hline Group & 1 & 7.205 & 0.265 & 0.014 \\
FAC1_1 & 1 & 2.508 & 0.111 & 0.129 \\
Group* FAC1_1 & 1 & 0.482 & 0.024 & 0.482 \\
Error (within groups) & 20 & & & \\
\hline
\end{tabular}

FAC1_1: TA, TB, LB, LD, PL, PS, PPu, and PB; $p<.05$

In Table 2, Pearson's correlation analysis indicated significant positive correlation between $\mathrm{PPa}$ and $\mathrm{PBe}$ to $\mathrm{BT}$ group III $(\mathrm{PPa} r(17)=0.965, p<0.01 ; \mathrm{PBe}$ $r(17)=0.567, p<0.01)$. In group I and group II, BT only has positive correlation with PPa (group I $r(7)=0.975, p<0.01$; group II $r(22)=0.932, p<0.01)$. In group III, TA (0.553), TB (0.633), LB (0.629), and PS (0.606) significantly correlates $(\mathrm{p}<0.05)$ with BT. In group II, TA $(0.444)$ significantly correlates $(\mathrm{p}<0.05)$ with BT. In group I, PS (0.792) positively correlates $(\mathrm{P}<0.05)$ with $\mathrm{BT}$. Linear bodyweight parameters on each group have a weak positive correlation to $\mathrm{BT}$ meanwhile $\mathrm{PPa}$ has a strong positive correlation to BT $(r>$ 0.90 ) within each group. Conclusively $\mathrm{PPa}$ can be used as a standardized BT estimation model within all chicken groups. Regression analysis was used to strengthen this conclusion as can be seen in Figure 3.

The non-linear regression model applied in this research was curvilinear quadratic because of improvement on $\mathrm{R}^{2}$ value compare to $\mathrm{R}^{2}$ in simple linear regression (Supplemental File 3, Table 4). $\mathrm{PPa}$ is the construction parameter of the prediction model suitable for a non-linear projection of BT in chicken groups I, II, and III. BT prediction model according to linear bodyweight parameter with positive weak correlation analyzed with ANCOVA in Table 3.

ANCOVA analysis between subject and factor [Chicken Group (I, II, and III); covariate: FAC1_1] showed significant group effect $\mathrm{F}(1.20)=7.205, \mathrm{p}=0.014, \eta 2$ $=0.265$, while FAC1_1, F $(1,20)=2.508$, $p=0.129, \eta 2=0.111$ was insignificant, and no interaction between group and FAC1_1, $\mathrm{F}(1.20)=0.482, \mathrm{p}=0.482, \eta 2=0.024$. ANCOVA analysis strengthening $\mathrm{PPa}$ parameter as 8-weeks-old Kambro Body Weight (BT) prediction model. Semakula et al. (2011) stated that native Lake Victoria chickens' live body weight correlates with chest girth. In that research live body 
weight prediction model and chest girth is non-linear regression highest $\mathrm{R}^{2}$ value on power model $\left(0.001 \mathrm{G}^{2.417}\right)$ (Semakula et al., 2011). Ukwu et al. (2014) stated that linear bodyweight parameters including shank length can be used as a live body weight prediction model of native Nigeria chicken. Mabelebele et al. (2017) stated that Broiler Ross 308 has distinguished femur and tibia length compare to Venda chicken, native South Africa chicken. A similar phenomenon can be observed in Pelung chicken with shorter PPa compare to Broiler Cobb 500, on the other hand, distinguished in PBe. Kambro chicken has $\mathrm{PPa}$ and $\mathrm{PBe}$ superior to parental generation (Fig. 2A). Mabelebele et al. (2017) stated that polynomial regression of Ross 308 carcass weight was inflicted $97 \%$ by femur length and $94 \%$ by tibia length, meanwhile, Venda chicken was inflicted $89 \%$ by tibia length and $37 \%$ by femur length. In this research the non-linear quadratic function for the bodyweight of Broiler Cobb 500 was affected by $97.8 \% \mathrm{PPa}, \mathrm{F}_{1}$ Pelung by $96.2 \%$ $\mathrm{PPa}$, and Kambro by $95.6 \% \mathrm{PPa}$. Conclusively PPa length growth coherently following BT growth in Kambro.

PPa function of Broiler Cobb 500 was higher than $\mathrm{F}_{1}$ Pelung can be caused by intensive rearing system. Pelung chicken is mostly reared with the extensive system or free-range with a variation of feed diets. Thus, $\mathrm{F}_{1}$ Pelung bone growth retardation can be caused by locomotion limitations. Henuk and Bakti (2018) stated that an extensive rearing system decrease native Indonesia chicken productivity because of feed diet inefficiency and a lengthy growth period of 90 days $/ 1 \mathrm{~kg}$. Femur length (PPa) growth adjusted with Body Weight (BT) in Broiler Cobb 500 with extensive rearing system and non-strict feed diet impacting negatively growth performance of fastgrowing broiler chickens (Pauwels et al., 2015). Regression analysis of group II PPa parameter showed declining BT by increasing length of PPa (Fig. 3). Broiler locomotion was affected by BT and PPa. A strict diet can cause musculoskeletal growth delay in the broiler with further implication muscle stress of movement and locomotion (Paxton et al., 2014). Shim et al. (2012) stated that the bone of a fast-growing broiler at 6-weeks-old is longer, wider, heavier, stronger, compact, and high calcium concentrated compared with a slow-growing broiler with the same age. Han et al. (2015) stated that the tibia is the longest and heaviest part compared with the femur as the longest diameter bone. The mortality rate and performance of broilertype chicken are affected by bone structure. Bone growth abnormality can be affected by several factors including the lighting period. Van der Pol et al. (2015) stated that a minimum lighting period decreases the environmental stress of chickens, where extreme dim-bright lighting increase asymmetric bone growth in the broiler. $\mathrm{PPa}$ function of Kambro was lower than $\mathrm{F}_{1}$ Pelung and Broiler Cobb 500 conclusively semi-intensive rearing system and nonstrict combination of feed diet can be standardized as suitable Kambro rearing system.

Market assessments and crossbreed selection depend on visual phenotype parameter appearance (Frame, 2009; Semakula et al., 2011; Assan, 2015). The visual method can be used to rapidly identify certain traits quality of chickens.

Navara et al. (2012) stated that phenotype appearance determines chickens' genetic succession and productivity. Based on LP group III was insignificant ( $\mathrm{p}>0.05)$ to group I (Supplemental File 3, Table 2). Based on PJ, TJ, and LK group III was insignificant ( $>0.05$ ) to group II (Fig. 2). The comb color of group III was dominated $58.82 \%$ by red color and $41.18 \%$ rosy color (Table 4) with $100 \%$ of the single shaped comb. Navara et al. (2012) stated that comb color has a positive significant correlation to sperm function, on the other hand, comb size has a negative significant correlation. These findings were contradictive with other findings which stated that comb size has a positive significant correlation to vitality, sperm function, and mating signal 
in males (Gebriel et al., 2009; El Ghany et al., 2011; Udeh et al., 2011). The dominant male showed a larger comb dimension $(\mathrm{PJ}+\mathrm{TJ})$ with bright red color with low sperm motility (Navara et al., 2012). Female inclination to select dominant male can cause quality reduction of filial generation sperm quality (Navara et al., 2012). Frame (2009) stated that comb color
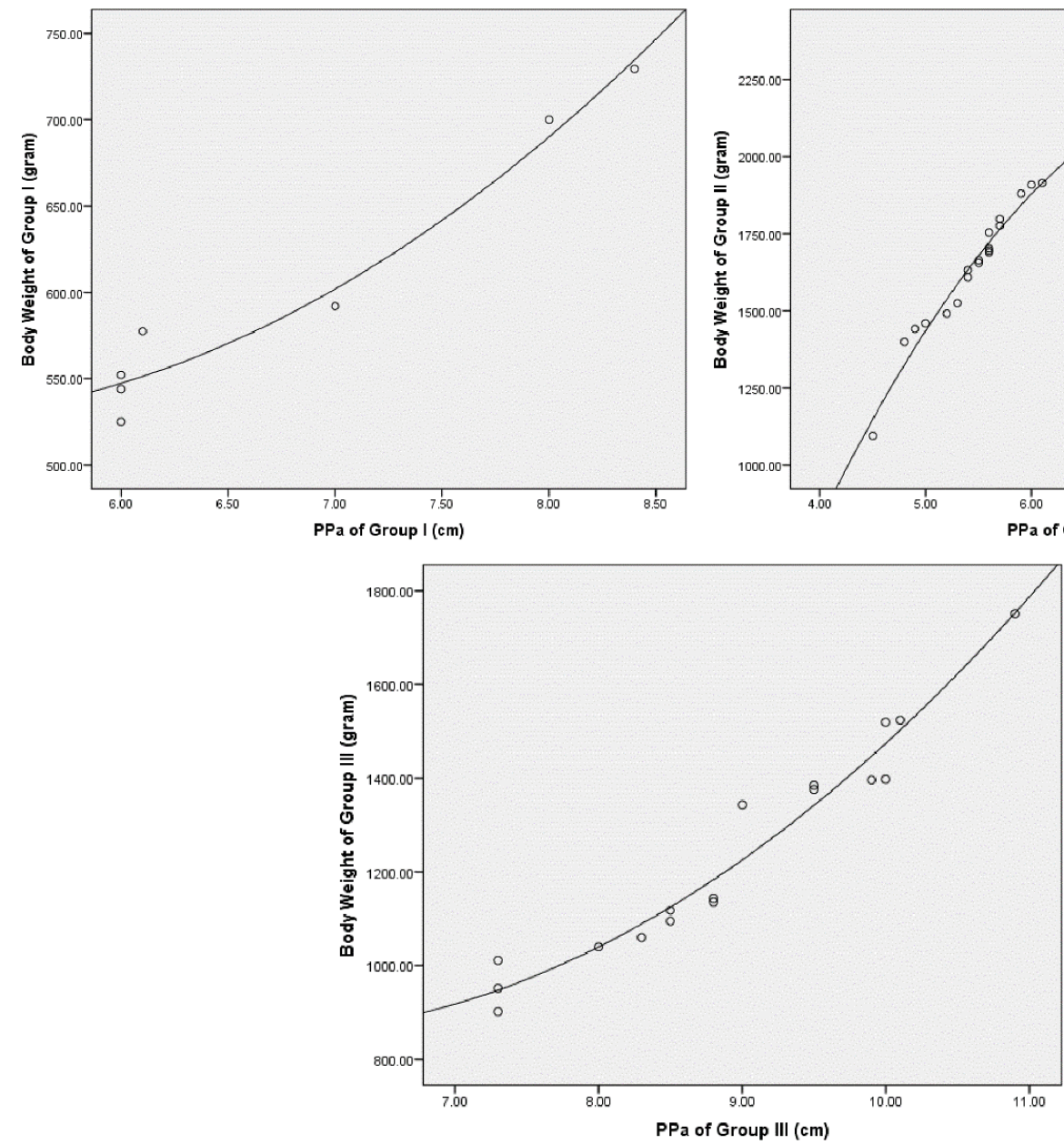

Figure 3. Curvilinear quadratic PPa model against BT chicken group I, II, and III.

Identification of comb color, PJ, and TJ in Kambro become parental selection guide, to sort out males with low sperm motility in future crossbreed. Based on these findings in the next crossbreed male with small PJ and TJ and female with bright red color will be chosen. Measurement on PK, LK, PP, and LP (Fig. 2B) is an indicator of dietary pattern and feed consumption rate with the correlative link between these parameter and Body Weight (BT) have been clarified by several studies

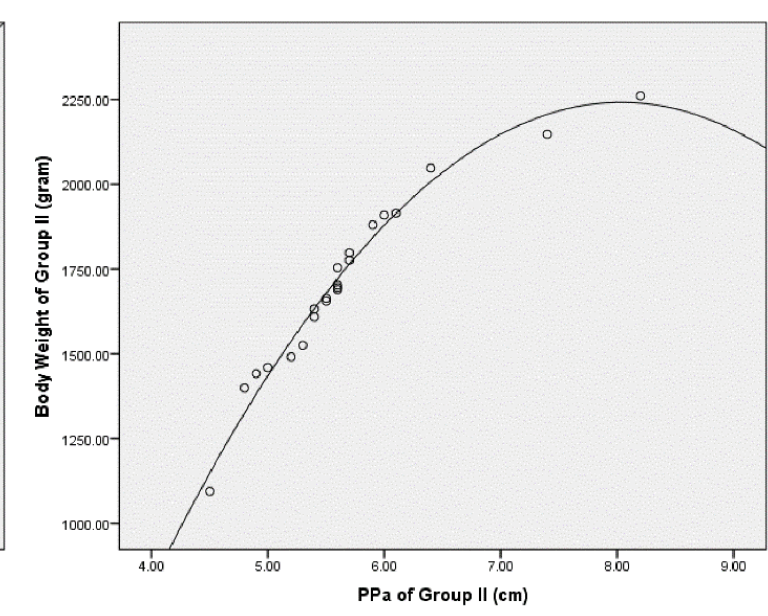

involves as an indicator of the laying period with pale-color indicates laying initiation and post-laying period while bright red color indicates optimum laying period. The average PJ of Kambro is $3.81 \pm 0.76 \mathrm{~cm}$ shorter than several other breed such as White Leghorn (10-16 cm), Red Junglefowl $(6-12 \mathrm{~cm})$, and broiler $(8-14 \mathrm{~cm})$ (Navara $e t$ al., 2012).

(Fahey et al., 2007; Yakubu et al., 2009; Fayeye et al., 2013; Joller et al., 2018). Beak deformity has been known to affecting dietary patterns and chickens' body weight (Joller et al., 2018) with the genetic influence of $D E G s$ gene expression (Bai et al., 2014). Beak color was dominated by ivory white color $(70.58 \%)$ followed by white, black patterned (29.42\%). Frame (2009) stated that fading of beak color from white into dull white or ivory white color indicates chicken age 
between 4 to 6 weeks old. Chicken shank color controlled by locus allele $I d$-id and $W$ $w$ with $I d$ - expressing white or yellow color and idid expressing black, gray, or green colors influenced by GRAMD3 gene in dermal tissue of shank (Xu et al., 2017). Frame (2009) stated that depigmentation of shank color is an indication of hen egg productivity during 15 to 20 weeks.

Feather expression in Pelung Blirik Hitam is determined by three genotypes $Z^{B} Z^{b}$ (patterned), $Z^{b} Z^{b}$ (plain), and Broiler Cobb 500 is determined by genotype $Z^{b} W$ (plain white). Hasnelly et al. (2017) stated that chicken feather color is expressed by $(s)$ allele for old golden color, $(S)$ for silver recessive, $(b)$ for plain color, $(B)$ for patterned color. Feather color in broiler chicken can be classified into dominant white which can be observed in White Leghorn chicken with several variations that are smoky/grayish $(I * S)$ and dun/whitish $(I * D / i)$ (Kerje et al., 2004). Both male Kambro $\left(Z^{B} Z^{b}\right)$ and female Kambro $\left(Z^{B} W\right)$ showed $100 \%$ gene frequencies of feather color with black patterns, brown, and gray. Pelung Blirik Hitam and Broiler Cobb 500 shank color genotype can be categorized as IdId/Id_ (white/yellow) and idid (black/gray/green). Both male Kambro and female Kambro shank color gene frequencies can be classified into three groups $I d I d /$ white $(52.95 \%)$, Idid/white with black pattern/gray $(41.17 \%)$, and idid/black $(5.88 \%)$. Body feather color and shank color variation of Kambro indicate segregation of alleles in the population inherited by Pelung Blirik Hitam and Broiler Cobb 500. Duguma (2006) stated that bright or white body feather color has higher commercial value and qualified by market. Semakula et al. (2011) stated that visual judgment has a significant influence on sale value with a tendency of increasing demand for native Ugandan chickens. Suprijatna (2010) stated that native Indonesia chickens have a niche market, and the prevalence of customers showed a higher demand on native chickens based on their unique taste and phenotypic appearance.

Table 4. Phenotype parameters of Kambro at 8-weeks-old based on visual observation scoring method.

\begin{tabular}{|c|c|c|c|c|}
\hline $\begin{array}{l}\text { Phenotype } \\
\text { Parameters }\end{array}$ & Characters & $\begin{array}{c}\text { Gene Frequency } \\
(\%) \\
\delta / 0(\mathrm{n}=17) \\
\end{array}$ & Locus & Gene \\
\hline Color of neck feather & White & 100 & $I-i$ & $q^{I}-q^{i}$ \\
\hline Back feather color & $\begin{array}{l}\text { White with black, brown, } \\
\text { and gray strands }\end{array}$ & 100 & $I-i / E-e+-e$ & $q^{I}-q^{i} / q^{E}-q^{e+}-q^{e}$ \\
\hline Color of chest hair & White & 100 & $I-i$ & $q^{I}-q^{i}$ \\
\hline Body feather color & $\begin{array}{l}\text { White with black, brown } \\
\text { and gray strands }\end{array}$ & 100 & $\begin{array}{l}I-i / E-e+- \\
\quad e / B-b\end{array}$ & $\begin{array}{c}q^{I}-q^{i} / q^{E}-q^{e+}- \\
q^{e} / q^{B}-q^{b}\end{array}$ \\
\hline \multirow{2}{*}{$\begin{array}{l}\text { Color of the femoral } \\
\text { feather }\end{array}$} & White & 52.95 & $I-i$ & $q^{I}-$ \\
\hline & $\begin{array}{l}\text { White black or gray } \\
\text { pattern }\end{array}$ & 47.05 & $E-e+-e / B-b$ & $q^{E}-q^{e+}-q^{e} / q^{B}-q^{b}$ \\
\hline \multirow{3}{*}{ Shank color } & White & 52.95 & $I d-i d$ & $q^{I d} / q^{i d}$ \\
\hline & $\begin{array}{l}\text { White black or gray } \\
\text { pattern }\end{array}$ & 41.17 & $I d-i d$ & $q^{I d} / q^{i d}$ \\
\hline & Black & 5.88 & $I d-i d$ & $q^{I d} / q^{i d}$ \\
\hline \multirow{2}{*}{ Comb color } & Red & 58.82 & - & - \\
\hline & Pink & 41.18 & - & \\
\hline Comb shape & Single & 100 & $P-p$ & $q^{P} / q^{p}$ \\
\hline \multirow{2}{*}{ Beak color } & Broken white & 70.58 & - & - \\
\hline & White black pattern & 29.42 & - & - \\
\hline
\end{tabular}




\section{CONCLUSION}

Based on the measurement of Body Weight (BT), Kambro (1,244.14 \pm 453.82 grams) performed significantly $(\mathrm{p}<0.01)$ better than $\mathrm{F}_{1}$ Pelung $(602.88 \pm 79.93$ grams) in 8 weeks with an ad libitum diet of standard feed. The performance escalation of Kambro compared with $\mathrm{F}_{1}$ Pelung was significantly based on the measurement of linear bodyweight parameter, vitality parameter, femur length ( $\mathrm{PPa})$, tibia length $(\mathrm{PBe})$, and phenotype parameter. Observation of phenotype parameter showed the resemblance of Kambro with parental generation. Estimation model of Kambro Body Weight (BT) can be measured with femur length $(\mathrm{PPa})$ in nonlinear quadratic regression $(r=0.956)$ based on this formula 1.84E $3 \pm$ $3.54 \mathrm{E} 2 * x+31.73 * x^{2}$. ANCOVA analysis showed no interaction between the group and linear bodyweight parameter and there was a significant difference in BT of groups $(\mathrm{p}=0.014)$. The mortality rate of Kambro was lower than $\mathrm{F}_{1}$ Pelung with the absence of vaccination in a semi-intensive rearing system. Research findings must be validated with a larger population size.

\section{SUGGESTION}

Further research with a larger number of hybrid chickens must be conducted to validate the result of this study.

\section{ACKNOWLEDGEMENT}

Research funding of Ministry of the Higher Education Republic of Indonesia. Gama Ayam Research Team and Agrotechnology Innovation Center Universitas Gadjah Mada.

\section{REFERENCES}

Ali M, Hossain MS, Akter S, Khan MAHNA, Hossain MM. 2013. Pathogenesis of infectious coryza in chickens (Gallus gallus) by Avibacterium paragallinarum isolate of
Bangladesh. The Agriculturists. 11(1): 39-46.

Anggitasari S, Sjofjan O, Djunaidi IH. 2016. Pengaruh beberapa jenis pakan komersial terhadap kinerja produksi kuantitatif dan kualitatif ayam pedaging. Bul. Peternakan. 40(3): 187196.

Assan N. 2015. Methodology and factors influencing the association of body weight, performance parameters with linear body measurements assessment in poultry. Sci. J. Pure. Appl. Sci.4(10): 200-210.

Bai H, Zhu J, Sun Y, Liu R, Liu N, Li D, Wen J, Chen J. 2014. Identification of genes related to beak deformity of chicken using digital gene expression profiling. PLOS ONE. 9(9): e107050.

Cheng HW. 2010. Breeding of tomorrow's chickens to improve well-being. Poult. Sci. 89: 805-813.

Darwati S, Hasyim AR, Rukmiasih, Prabowo S. 2016. Growth performance of Pelung sentul kampung meat type chicken crossing on age 0-10 weeks. Marjuki, Ridlowi A, Jaya F,Susilowati $\mathrm{T}$, Wittayakun S, Bottema CDK, Alimon AR, Hsia LC, Thiruvenkadan AK, editors. Proceeding of the 3rd Animal Production International Seminar (3rd APIS) \& 3rd ASEAN Regional Conference on Animal Production (3rd ARCAP). Batu (Indones): Universitas Brawijaya. Pp. 484-487.

Daryono BS, Roosdianto I, Saragih HTS. 2010. Pewarisan karakter fenotip ayam hasil persilangan ayam Pelung dengan ayam cemani. J. Vet. 11(4): 257-263.

Das SC, Chowdhury SD, Khatun MA, Nishibori M, Isobe N, Yoshimura Y. 2008. Poultry production profile and expected future projection in Bangladesh. World's Poult. Sci. Assoc. 64: 99-118.

Direktorat Jenderal Peternakan dan Kesehatan Hewan. 2017. Statistik 
Peternakan dan Kesehatan Hewan 2017 Livestock and Animal Health Statistics 2017. [accessed: April 29 $\left.{ }^{\text {th }} 2019\right]$. http://ditjenpkh.pertanian.go.id/userfile s/File/Buku_Statistik_2017_(ebook).pd f?time $=150512744 \quad 3012$

Direktorat Jenderal Peternakan dan Kesehatan Hewan. 2018. Statistik Peternakan dan Kesehatan Hewan 2018 Livestock and Animal Health Statistics 2018. [accessed: April 29 $\left.9^{\text {th }} 2019\right]$. http://ditjenpkh.pertanian.go.id/userfile s/File/Buku_Statistik_2017_(ebook).pd f?time $=150512744 \quad 3012$

Diwyanto K, Prijono SN. 2007. Keanekaragaman sumber daya hayati ayam lokal Indonesia: manfaat dan potensi. Bogor (Indones): Lembaga Ilmu Pengetahuan Indonesia.

Duguma R. 2006. Phenotypic characterization of some indigenous chicken ecotypes of Ethiopia. Livestock Res. Rural Dev. 18(9): 131.

El Ghany FAA, El Dein A, Soliman MM, Rezaa AM, El Sodany SM. 2011. Relationships between some body measurements and fertility in males of two local strains of chicken. Egypt Poult. Sci. 31:331-349.

Fahey AG, Marchant-Forde RM, Cheng HW. 2007. Relationship between body weight and beak characteristics in oneday-old White Leghorn chicks: Its Implications for Beak Trimming. Poult. Sci. 86: 1312-1315.

Fayeye TR, Hagan JK, Obadare AR. 2013. Morphometric traits and correlation bet ween body weight and body size traits in Isa Brown and Ilorin ecotype chickens. Iranian J. Appl. Anim. Sci. 4(3): 609-614.

Gebriel GM, Kalamah MA, El-Fiky AA, Ali AFA. 2009. Some factors affecting semen quality traits in norfa cocks. Egypt Poult. Sci. 29: 677-693.

Hameed T, Mustafa MZ, Taj MK, Asadullah, Bajwa MA, Bukhar FA, Kiani MMT, Ahmed A. 2016. Hatchability and fertility in broiler breeder stock. J. Chem. Biol. Phy. Sci. 6(2): 266-274.

Han JC, Qu HX, Wang JG, Chen GH, Yan YP, Zhang JL, Hu FM, You LY, Cheng YH. 2015. Comparison of the growth and mineralization of the femur, tibia, and metatarsus of broiler chicks. Braz. J. Poult. Sci. 17(3): 333-340.

Hasnelly, Iskandar S, Sartika T. 2017. Karakteristik kualitatif dan kuantitatif ayam SenSi-1 Agrinak. JITV. 22(2): 6879.

Hassan KMd, Kabir HMd, Sultana S, Hossen AMd, Haq MM. 2016. Management and production performance of Cobb-500 broiler parent stock under open housing system. Asian Australas. J. Biosci. Biotechnol. 1(1): 66-72.

Hasyim AR. 2015. Performa hasil persilangan ayam kampung ras pedaging dengan Pelung sentul pada umur 0-11 minggu (Thesis). [Bogor: (Indonesia)]: Institut Pertanian Bogor.

Henuk YL, Bakti D. 2018. Benefits of Promoting Native Chickens for Sustainable Rural Poultry Development in Indonesia. Mohammad Basyuni, S. Hut., M.Si., Ph.D., Prof. Dr. Ir. Elisa Julianti, M. Si, editors. Conference Proceeding of Seminar Ilmiah Nasional Dies Natalis USU-64. Sumatera Utara (Indones): University of Sumatera Utara. Pp. 69-76.

Iskandar S. 2017. Petunjuk tenis produksi ayam lokal pedaging unggul (Program Perbibitan Tahun 2017). Edisi 2017. Bogor (Indonesia): Pusat Penelitian dan Pengembangan Peternakan. Pp. 1-43.

Joller S, Bertschinger F, Kump E, Spiri A, von Rotz A, Schweizer-Gorgas D, Drogemuller C, Flury C. 2018. Crossed beaks in a local swiss chicken breed. BMC Vet. Res. 14: 68.

Kartika AA, Widayati KA, Burhanuddin, Ulfah A, Farajallah A. 2016. Eksplorasi preferensi masyarakat terhadap pemanfaatan ayam lokal di Kabupaten Bogor Jawa Barat. J. Ilmu Pertanian Indonesia (JIPI). 21(3): 180-185. 
Kerje S, Sharma P, Gunnarsson U, Kim H, Bagchi S, Fredriksson R, Schutz K, Jensen P, von Heijne G, Okimoto R, Andersson L. 2004. The dominant white, dun and smoky color variants in chicken are associated with insertion/deletion polymorphisms in the PMEL17 Gene. Genetics. 168: 15071518.

Mabelebele M, Norris D, Siwendu NA, Ng'ambi JW, Alabi OJ, Mbajiorgu CA. 2017. Bone morphometric parameters of the tibia and femur of indigenous and broiler chickens reared intensively. Appl. Ecol. Environ. Res. 15(4): 13871398.

Mariandayani HN, Darwati S, Sutanto E, Sinaga E. 2017. Peningkatan produktivitas ayam lokal melalui persilangan tiga rumpun ayam lokal pada generasi kedua. Prosiding Seminar Nasional Biologi 2017: Pendidikan Biologi untuk Masa Depan Bumi. Aceh (Indones): Jurusan Pendidikan Biologi, Universitas Syiah Kuala. Pp. 139-146.

Mariandayani HN, Solihin DD, Sulandari S, Sumantri C. 2013. Keragaman fenotipik dan pendugaan jarak genetik pada ayam lokal dan ayam broiler menggunakan analisis morfologi. $J$. Vet. 14(4): 475-484.

Nataamijaya AG. 2010. Pengembangan potensi ayam lokal untuk menunjang peningkatan kesejahteraan petani. $J$. Litbang. Pertanian. 29(4): 131133.

Navara KJ, Anderson EM, Edwards ML. 2012. Comb size and color relate to sperm quality: a test of the phenotypelinked fertility hypothesis. Behav. Ecol. 12: 1036-1041

Ningsih R, Prabowo DW. 2017. Tingkat integrasi pasar ayam broiler di sentra produksi utama: studi kasus Jawa Timur dan Jawa Barat. Bul. Ilmiah Litbang Perdagangan. 11(2): 247-270.

Nurfadillah S, Rachmina D, Kusnadi N. 2018. Impact of trade liberalization on Indonesian broiler competitiveness. $J$. Indon. Trop. Anim. Agri. 43(4): 429437.
Nurhuda SA. 2017. Pertumbuhan generasi ketiga hasil persilangan ayam lokal dengan ayam ras pedaging sampai umur 12 minggu (Thesis). [Bogor: (Indones)]: Institut Pertanian Bogor.

Nuroso. 2010. Ayam kampung pedaging hari per hari. Jakarta, Penebar Swadaya.

Oldenbroek K, van der Waaij L. 2014. Textbook animal breeding: animal breeding and genetics for BSc students. Centre for Genetic Resources (Netherlands): The Netherlands and Animal Breeding and Genomics Centre.

Pauwels J, Coopman F, Cools A, Michiels J, Fremaut D, de Smet S, Janssens GPJ. 2015. Selection for growth performance in broiler chickens associates with less diet flexibility. PLOS ONE. 10(6): e0127819.

Paxton H, Tickle PG, Rankin JW, Codd JR, Hutchinson JR. 2014. Anatomical and biomechanical traits of broiler chickens across ontogeny. Part ii. Body segment inertial properties and muscle architecture of the pelvic limb. Peer J. 2: e473.

Pusat Data dan Sistem Informasi Pertanian. 2015. Outlook Komoditas Pertanian Sub Sektor Peternakan Daging Ayam. [accessed: April 29 ${ }^{\text {th }}$ 2019]. http://epublikasi.setjen.pertanian.go.id/ download/file/213-outlook dagingayam-2015

Rahman MR, Chowdhury SD, Hossain ME, Ahammed M. 2015. Growth and early laying performance of a broiler parent stock in an open-sided house under restricted feeding. Bangladesh J. Anim. Sci. 44(1): 40-45.

Semakula J, Lusembo P, Kugonza DR, Mutetikka D, Ssennyonjo J, Mwesigwa M. 2011. Estimation of live body weight using zoometrical measurements for improved marketing of indigenous chicken in the Lake Victoria basin of Uganda. Livestock Res. Rural. Dev. 23(8).

Shim MY, Karnuah AB, Mitchell AD, Anthony NB, Pesti GM, Anggrey SE. 2012. The effects of growth rate on leg 
morphology and tibia breaking strength, mineral density, mineral content, and bone ash in broilers. Poult. Sci. 91: 1790-1795.

Sogindor BA. 2017. Performa pertumbuhan hasil persilangan ayam lokal dengan ayam ras pedaging umur 1 sampai 12 minggu (Thesis). [Bogor]: Institut Pertanian Bogor

Solikin T, Tanwiriah W, Asmara IY. 2016. Bobot akhir, bobot karkas, dan income over feed and chick cost ayam sentul Barokah Abadi Farm Ciamis. Stud. e-J. Fakultas Peternakan Universitas Padjadjaran. 5(4): 1-9.

Sudrajat, Isyanto AY. 2018. Keragaan peternakan ayam sentul di Kabupaten Ciamis. J. Pemikiran Masyarakat Ilmiah Berwawasan Agribisnis. 4(2): 237-253.

Suprijatna E. 2010. Strategi pengembangan ayam lokal berbasis sumber daya lokal dan berwawasan lingkungan. Seminar Nasional Unggas Lokal ke IV. Sunarti D, Suprijatna E, Mahfudz LD, Sarengat W, Karno, Nuswantara LK, Surono, Sarjana TA, penyunting. Bogor (Indones): Fakultas Peternakan Universitas Diponegoro. Pp. 55-88.

Tamzil MH, Lestari L, Indarsih B. 2018. Measurement of several qualitative traits and body size of Lombok Muscovy ducks (Cairina moshcata) in semi-intensive rearing. J. Indon. Trop. Anim. Sci. 43(4): 333-342.

Udeh I, Ugwu SOC, Ogagifo NL. 2011. Predicting semen traits of local and exotic cocks using linear body measurements. Asian J. Anim. Sci. 5: 268-276.

Ukwu HO, Okoro VMO, Nosike RJ. 2014. Statistical modelling of body weight and linear body measurements in Nigerian indigenous chicken. IOSR $J$. Agri. Vet. Sci. 7(1): 27-30.

van der Pol CW, Molenaar R, Buitink CJ, van Roovert-Reijrink IAM, Maatjens CM, van den Brand H, Kemp B. 2015. Lighting schedule and dimming period in early life: consequences for broiler chicken leg bone development. Poult. Sci. 94: 2980-2988.

Xu J, Lin S, Gao X, Nie Q, Luo Q, Zhang X. 2017. Mapping of id locus for dermal shank melanin in a Chinese indigenous chicken breed. J. Gen. 96(6): 977-983.

Yakubu A, Kuje D, Okpeku M. 2009. Principal components as measures of size and shape in Nigerian indigenous chickens. Thai. J. Agri.Sci. 42(3): 167176. 